\title{
En kvinne i 60-årene med kløe på armene
}

\author{
En ellers frisk kvinne hadde i tre år hatt svært plagsom kløe på begge \\ armers strekkeside. Hun hadde fors økt «alle» typer kremer, inkludert \\ kortisonkremer, uten effekt. Selv om kløe ofte er forårsaket av vanlige \\ hudsykdommer, viser denne pasienthistorien at en tverrfaglig tilnær- \\ ming kan være nyttig.
}

Pasienten, en kvinne $i$ begynnelsen av 60årene, ble henvist til hudpoliklinikken på grunn av daglig sterk kløe på begge armene. Hun klorte og skrapet seg i huden slik at hun av og til blødde. Kløen gikk utover søvnen. Det lindret å legge isposer mot huden.

Kløen hadde startet på venstre arms strekkeside sommeren tre år før første konsultasjon på hudpoliklinikken. Etter et par måneder var kløen like intens på høyre arm. Etter hvert kom det også kløe på ryggen.

Kronisk kløe, eller kronisk pruritus, er en relativt vanlig helseplage. En norsk studie viste at ca. $9 \%$ av alle voksne i Oslo rapporterte «en del» eller «mye kløe i huden» siste uke (1). Det er mange årsaker til kløe. Mest vanlig er sykdommer i huden, som eksem, psoriasis og elveblest (urticaria).

Kronisk kløe er forårsaket av hudsykdommer, systemiske sykdommer (inkludert svangerskapssykdommer og legemiddelutløst kløe), nevrologiske sykdommer eller psykiatriske sykdommer (2). I noen tilfeller er det mer enn én årsak til kløen, andre ganger kan eventuell underliggende sykdom ikke identifiseres (2).

Pasienten var tidligere hudfrisk, hun hadde ingen allergier og det var ingen hudsykdommer $i$ hennes slekt. Hun hadde brukt acetylsalisylsyre $i$ over ti år etter et transitorisk iskemisk anfall, men tok ellers ingen faste medikamenter. Hele sitt voksne liv hadde hun hatt hyppig hodepine og nakkesmerter som muligens kunne relateres til en bilulykke med nakkesleng da hun var i slutten av tenårene. Det ble den gang ikke påvist frakturer eller nevrologiske utfall.

Ved klinisk hudundersøkelse var det på begge armers ekstensorside multiple ekskoriasjonsmerker og hvitlige arrforandringer, men ingen primærefflorescenser (fig 1) Hun hadde ikke pareser, smerter eller parestesier i armene.

Dersom en pasient med kronisk kløe har primærefflorescenser slik som makler, papler, noduli, plakk, vesikler, bullae, pustler eller urticaria, er det sannsynlig at en hudsykdom er årsak til eller medvirkende årsak til kløen. Hos vår pasient var det kun sekundærefflorescenser - arrforandringer og ekskoriasjonsmerker - så både dermatologiske, systemiske, nevrologiske og psykiatriske årsaker måtte vurderes.

Pasienten hadde ingen symptomer som ga mistanke om systemsykdom, som for eksempel nyresvikt, leversykdom eller stoffskiftesykdom. Orienterende blodprøver tatt hos fastlege var normale. Konsultasjonen ga ingen holdepunkter for psykiatrisk sykdom. Anamnesen passet ikke med gjennomgått herpes zoster.

Symptomene passet bra med tilstanden brakioradial kløe. Dette er en tilstand som er karakterisert ved kløe dorsolateralt på armene (3). Patogenesen er lite kjent. De to vanligste teoriene er at brakioradial kløe er forårsaket av langvarig ultrafiolett stråling mot huden og/eller nervekompresjon som følge av sykdommer i cervikalcolumna (3).

Pasienten hadde gjennom livet vært mye $i$ solen, og vinteren før plagene startet hadde hun oppholdt seg fire måneder i det sørlige Europa.

Hun hadde vært hos flere leger og var blitt forskrevet kortisonkremer i forskjellig styrke, antimykotiskekremer, antibakteriellekremer, antihistamintabletter og capsaicinkrem. Hun hadde smurt huden med capsaicin 1-2 ganger per døgn i noen uker. Verken denne kremen eller noen av de andre behandlingene hadde så langt hjulpet. Hun var ganske fortvilet over kløen, som ga henne betydelige plager.

Capsaicinkrem $0,075 \%$ er klassifisert som et lokalanestetikum. Indikasjonen er postherpetiske smerter. Effekten av capsaicin er ikke veldokumentert ved brakioradial kløe, men det finnes flere kasuistikker der effekten har vært god (4).

Siden pasienten hadde hatt en nakkeskade i ungdommen, ønsket vi å få henne undersøkt av nevrolog.

Fokusert nevrologisk undersøkelse viste lett nedsatt sensibilitet for stikk på venstre 5 . finger og medialt på underarmen. I tillegg beskrev pasienten diffus økt følsomhet for både lett berøring (Somedic-børste) og stikk $i$ området med kløe, uten at det var sikker

\author{
Jon Anders Halvorsen \\ j.a.halvorsen@medisin.uio.no \\ Institutt for klinisk medisin \\ Universitetet i Oslo \\ og \\ Seksjon for hudsykdommer \\ Oslo universitetssykehus, Rikshospitalet

\section{Kristin Ørstavik} \\ Klinisk nevrofysiologisk laboratorium \\ og
}

Enhet for medfødte og arvelige nevromuskulære tilstander (EMAN)

Nevrologisk avdeling

Oslo universitetssykehus 


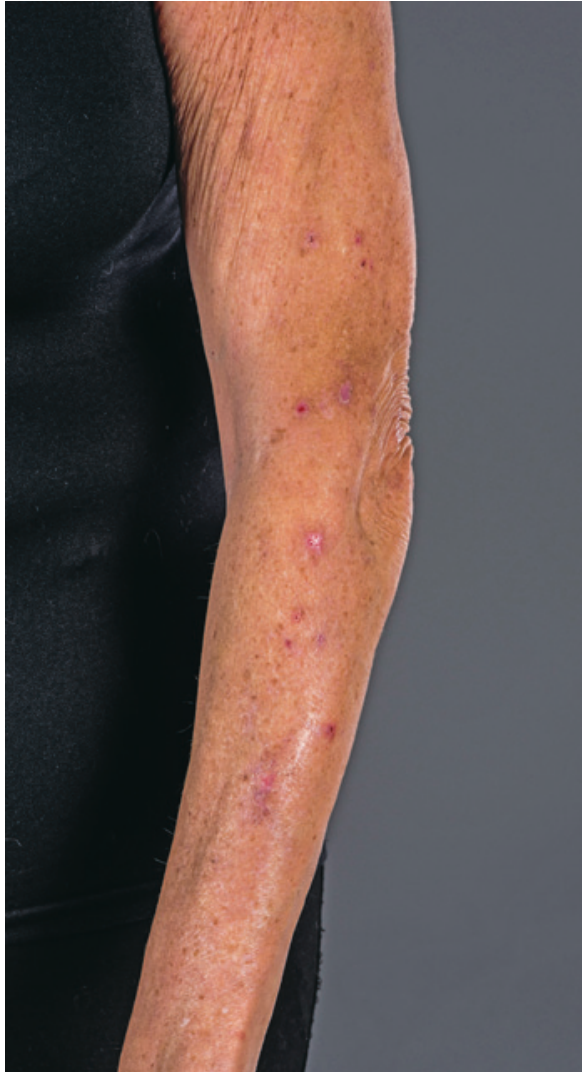

Figur 1 Vår pasient med eksoriasjoner og arrforandringer dorsolateralt på venstre arm. Foto: Kristin Ellefsen, Foto- og videotjenesten, Institutt for klinisk medisin, Universitetet i Oslo

mekanisk allodyni lsmerter ved lett berøring) eller hyperalgesi løkt smertefølelse) og heller ikke sikker alloknesis løkt kløe ved mekanisk stimulering). For øvrig var det normal nevrologisk status i overekstremitetene, inklusive reflekser. Nevrografi og elektromyelografi (EMG) kunne ikke påvise nedsatt funksjon i tykke nervefibre.

Det ble supplert med undersøkelse av de tynne nervefibrene med termotest, en psykofysisk test som særlig avdekker funksjonen til de afferente tynne nervefibrene la-delta og Cfibrel (5). Det ble undersøkt på terskler for varme, kulde, varmesmerte- og kuldesmerteterskler lateralt og medialt på begge overarmer etter først å ha latt pasienten teste ut metoden $i$ håndflaten. Hun hadde lateralt på begge overarmer forhøyede terskler for varmedeteksjon sammenliknet med medialside. Tersklene var på henholdsvis $35^{\circ} \mathrm{C}$ og $35,7^{\circ} \mathrm{C}$ på høyre og venstre arm medialt, mens de var $40,9^{\circ} \mathrm{C}$ og $44,5^{\circ} \mathrm{C}$ på laterale deler av overarmen. Kuldedeteksjons- og varmesmertedeteksjontersklene var ikke signifikant forskjellige på de målte områdene.

Supplerende MR-undersøkelse av nakken viste degenerative forandringer med noe reduserte plassforhold i foramina i femte og særlig sjette skivenivå.
Ut fra kliniske og radiologiske funn fant man ikke grunnlag for å utrede videre med tanke på kirurgisk intervensjon. Pasienten hadde allerede forsøkt capsaicinkrem. Hun ble overtalt til å forsøke en gang til, og ble denne gangen bedt om å påføre kremen 4-6 ganger per døgn de første ukene. Det ble også forskrevet klobetasol kortisonkrem.

Capsaicinkremen førte til betydelig svie og ubehag i huden de første dagene, men ved kontroll ni uker etterpå var pasienten nesten kvitt kløen. Hun mente selv at capsaicinkremen hadde vært mer effektiv enn kortisonkremen. Vi konkluderte med at pasienten hadde brakioradial kløe, men kunne ikke si noe sikkert om årsaken til hudkløen hos denne pasienten.

\section{Diskusjon}

Ved brakioradial kløe (eng. brachioradial pruritus) er det kliniske bildet kløe dorsolateralt på en eller begge armer. Plagene kan lindres av å legge isposer på huden (the icepack sign) (3). Dette passet bra med symptomene hos vår pasient. Noen pasienter kan beskrive brenning og prikking i huden i tillegg til kløe (6). Det kan også være kløe på skuldre og øvre thorax. Plagene kan progrediere, og affeksjon av større hudområder etter hvert er beskrevet (6). Symptomene kan bli verre om sommeren (3). Ved inspeksjon ses vanligvis kløemerker, lichenifisering eller kløeknuter (prurigo), men ikke dermatitt.

Brakioradial kløe ble første gang beskrevet i 1968 hos pasienter i Florida, USA (7). De neste rapportene kom også fra tropiske eller subtropiske områder i Sør-Afrika (14 pasienter) og Hawaii (110 pasienter). Frem til 2010 var det publisert 13 pasientserier med totalt ca. 450 pasienter (3). Brakioradial kløe synes ut fra litteraturen å være vanligst hos lyshudede som bor i områder med mye sol og hos kvinner (4). Tilstanden er ikke beskrevet hos barn (4). Prevalensen er ukjent, og tilstanden kan være underdiagnostisert

Patogenesen er ukjent, men kompresjon av perifere nerver og langvarig eksposisjon for ultrafiolett lys er mulige årsaker (4). Hos 16 svenske pasienter ble det $\mathrm{i}$ hudbiopsier påvist redusert antall intraepidermale nervefibre sammenliknet med kontrollpersoner, og dette ble tolket som UV-indusert skade (8). På den annen side er det i flere artikler vist at det hos en høy andel av pasientene med brakioradial kløe er påvist radiologiske forandringer i nakkevirvlene, og det virker som andelen er høyere enn forventet (4).

Vår pasient hadde MR-forandringer som viste lett påvirkning cervikalt $\mathrm{i}$ femte og sjette skivenivå samt forøkede termale terskler for varme i C5/C6-området på overarmen. Disse funnene kan altså tyde på en affeksjon av tynne nervefiberbaner i dette området, noe som kunne skyldes proksimal påvirkning på nerverøtter. Årsaken hos vår pasient kunne også være UV-indusert redusert antall tynne nervefibre i epidermis, som beskrevet i den svenske studien (8).

Kløe formidles normalt av afferente Cfibre som går fra epidermis til sentralnervesystemet. Histamin stimulerer én gruppe mekanoinsensitive C-fibre. En annen gruppe polymodale C-fibre (temperatur- og mekanosensitive) stimuleres av andre substanser enn histamin, for eksempel av bestanddeler fra den tropiske planten Mucuna pruriens (eng. cowage, dansk fløjlsbønne/kløende bønne) (9). Ifølge Wikipedia inneholder kløpulver som selges i morobutikker bestanddeler fra denne planten.

Disse C-nervefibrene hører til samme undergruppe av nervefibre som formidler varme, kulde og smerte. Det at noen pasienter med brakioradial kløe har beskrevet ulike typer sensoriske symptomer, kan indikere at denne delen av nervesystemet primært er involvert (6). En annen mulighet er at kronisk kloring på huden kan endre hudstrukturen, gjøre denne fortykket og dermed heve terskelen for varmesensitivitet (endrede termale terskler).

Diagnosen brakioradial kløe stilles ut fra det kliniske bildet. Det kan være aktuelt å ta hudbiopsi for å avdekke hudsykdom som årsak til kløen og utrede med tanke på porfyria cutanea tarda og sykdommer i cervikalcolumna. MR-undersøkelse av nakken kan vurderes, og ved patologiske funn bør pasienten utredes nevrologisk. I en serie med 111 pasienter fra USA ble 31 henvist til nevrolog og hos åtte ble radikulopati eller perifer nevropati påvist som sannsynlig årsak (3).

Behandlingen av brakioradial kløe er dårlig dokumentert og kan være utfordrende. I en liten studie med 13 pasienter kunne man ikke påvise bedre effekt av $0,025 \%$ capsaicinkrem enn av placebokrem (lavere konsentrasjon enn tilgjengelig preparat i Norge) (10). Flere kasuistikker viser effekt av capsaicinkrem (4). Det er viktig at pasienten er klar over at denne kremen kan gi stort ubehag, med smerter, brenning og stikking i huden i starten av behandlingen, men at dette etter hvert vil avta (4). I starten av behandlingen kan pasienten eventuelt blande capsaicinkremen med vanlig fuktighetskrem slik at konsentrasjonen blir lavere, for eksempel en femti-femti-blanding.

Antiepileptika og antidepressiver som brukes ved nevropatisk smerte, kan også ha effekt på brakioradial kløe, for eksempel gabapentin 900-2 $700 \mathrm{mg}$ daglig, pregabalin 300-450 mg daglig eller amitryptilin $25 \mathrm{mg}$ daglig (4). Vellykket behandling med lamotrigin er også beskrevet (11). Det er også enkeltrapporter på nakkemanipulasjon 
og akupunktur som hjelper (4). Hos én pasient ga kirurgisk diskotomi (C5-C6) og C6nerverotsdekompresjon remisjon (12). I tillegg kan solbeskyttelse og nedkjøling av huden være nyttige råd.

Brakioradial kløe er en tilstand som bør bli bedre kjent. Vi har her beskrevet en pasient som nærmest ble kvitt sine plager ved bruk av capsaicinkrem. Tilstanden kan være karakteristisk, men etiologien er uklar.

Pasienten har samtykket til at artikkelen blir publisert.

\section{Jon Anders Halvorsen (f. 1968)}

er ph.d. og spesialist i hud- og veneriske sykdommer, overlege, seksjonsleder og førsteamanuensis.

Forfatter har fylt ut ICMJE-skjemaet og oppgir ingen interessekonflikter.

\section{Kristin Ørstavik (f. 1963)}

er dr.med. og spesialist i nevrologi og i klinisk nevrofysiologi, overlege og seksjonsleder. Forfatter har fylt ut ICMJE-skjemaet og oppgir ingen interessekonflikter.

\section{Litteratur}

1. Dalgard F, Svensson A, Holm JØ et al. Self-reported skin morbidity in Oslo. Associations with sociodemographic factors among adults in a cross-sectional study. Br J Dermatol 2004; 151: 452-7.

2. Ständer S, Weisshaar E, Mettang T et al. Clinical classification of itch: a position paper of the International Forum for the Study of Itch. Acta Derm Venereol 2007; 87: 291-4.

3. Mirzoyev SA, Davis MDP. Brachioradial pruritus: Mayo Clinic experience over the past decade. Br J Dermatol 2013; 169: 1007-15.

4. Marziniak M, Ständer S. Brachioradial Pruritus. I: Misery L, Ständer S, red. Pruritus. Berlin: Springer Verlag, 2010.

5. Jørum E, Warncke T, Ørstavik K. Tynnfibernevropati. Tidsskr Nor Legeforen 2013; 133: 179-83.

6. Kwatra SG, Ständer S, Bernhard JD et al. Brachioradial pruritus: a trigger for generalization of itch. J Am Acad Dermatol 2013; 68: 870-3.

7. Waisman M. Solar pruritus of the elbows (brachioradial summer pruritus). Arch Dermatol 1968; 98: $481-5$.

8. Wallengren J. Sundler F. Brachioradial pruritus is associated with a reduction in cutaneous innervation that normalizes during the symptom-free remissions. J Am Acad Dermatol 2005; 52: 142-5.

9. Dhand A, Aminoff MJ. The neurology of itch. Brain 2014: 137: 313-22

10. Wallengren J. Brachioradial pruritus: a recurrent solar dermopathy. J Am Acad Dermatol 1998; 39: 803-6.

11. Crevits L. Brachioradial pruritus - a peculiar neuropathic disorder. Clin Neurol Neurosurg 2006; 108: 803-5

12. Binder A, Fölster-Holst R, Sahan $G$ et al. A case of neuropathic brachioradial pruritus caused by cervical disc herniation. Nat Clin Pract Neurol 2008; 4: 338-42. 